\title{
WALTER ISARD
}

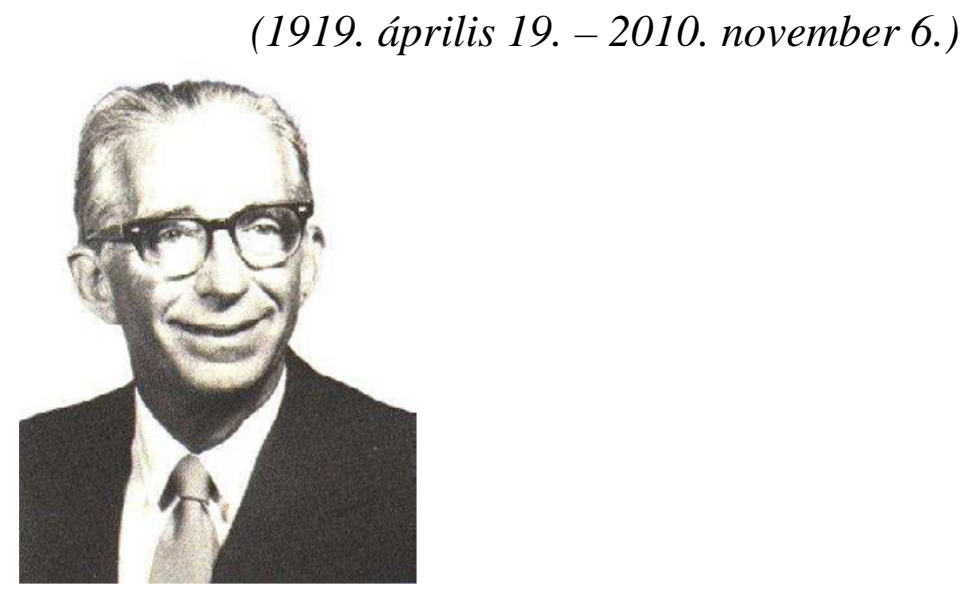

91 éves korában, 2010. november elején elhunyt Walter Isard, aki a regionális gazdaságtan, a területi elemzések és az általános térbeli egyensúly-elmélet kutatásában jelentős iskolateremtő egyéniség volt. Isard a regionális tudomány elindításában és megszerveződésében, intézményeinek létrehozásában is kiemelkedő szerepet töltött be ${ }^{1}$.

Walter Isard bevándorló szülők gyermekeként 1919-ben Philadelphiában született. Először a Temple University-n matematikai, majd 1939-től a Harvard University-n közgazdaságtani tanulmányokat folytatott, ezt követően 1941-42-ben a University of Chicago matematikai és közgazdaság-elméleti képzésében vett részt. Tudományos érdeklődési területének kialakulásában lényegesnek tünik, hogy az 1940-es években ő fordított le angolra több német nyelvü alapvető elhelyezkedéselméleti (location theory) munkát, pl. Weber, Lösch és Predöhl jelentős müveit.

A Nobel-díjas Leontief hívására részt vett a Harvard Egyetemen 1949-1953 között input-output modellek kidolgozásában, miközben a közgazdászok képzésében elhelyezkedés-elméletet és regionális fejlődési ismereteket oktatott. Érdeklődési területén aktív szervező munkát is végzett, 1948-tól, 29 éves korától az Amerikai Közgazdasági Társaság (AEA, American Economic Association) éves közgyülésein és egyéb rendezvényein több, területi és városi problémákkal foglalkozó szekciót szervezett nemcsak közgazdászok, hanem földrajzosok, szociológusok és demográfusok bevonásával.

Isard az M.I.T.-re (Massachusetts Institute of Technology) 1954-ben kapott meghívást a Városi és Regionális Tervezési Tanszék (Department of City and Regional Planning) docensi (associate professor) állására regionális gazdaságtant oktatni, egyúttal a Városi és Regionális Kutatások (Section of Urban and Regional Studies) részleg vezetője lett. Itt a közgazdász, illetve földrajzos, várostervező, szociológus hallgatók egy érdeklődő csoportját bevonva aktív tudományszervezői munkásságot folytatott. A feljegyzések szerint élénk viták folytak arról, hogy mi legyen a társa- 
dalom és gazdaság térbeli kérdéseivel komplexen foglalkozó, interdiszciplináris témakör neve, ami lefedi lényegét és nevében is eltér a már létező tudományágaktól. A viták során 1954-ben Isard javaslatára fogadták el a regionális tudomány (regional science) elnevezést. A Regionális Tudományi Társaság (RSA, Regional Science Association) 1954 végén tartotta alakuló ülését 60 kutató részvételével Detroit-ban, ahol az összejövetelen 25 előadás hangzott el. Formálisan 1956-ban legitimálódott, mint társadalomtudományi tudományág, amikor csatlakozott a Társult Társadalomtudományi Társaság (Allied Social Science Association) szervezethez.

Walter Isard 1956-ban az M.I.T.-ről átment a University of Pennsylvania egyetemre, Philadelphiába, mivel ott létrehozhatott egy regionális tudományi doktori $(\mathrm{PhD})$ programot, egyúttal megalapította és vezette a Regionális Tudományi Kutatóintézetet (Regional Science Research Institute), valamint az 1958-tól létrejövő Regionális Tudományi Tanszéket (Regional Science Department) is. Ekkor indította el a Journal of Regional Science folyóiratot is. Ezen az egyetemen regionális tudományból 1960 és 1993 között 180 fő kapott doktori fokozatot és 350 fö mester szintü diplomát, regionális tudományból az első PhD-t William Alonso szerezte 1960-ban városi területhasználati kutatásaiért.

Isard tevékeny közremüködésével az RSA igen intenzív tudományszervezést folytatott, rendezvények sokaságát menedzselték, folyóiratok, könyvsorozatok jöttek létre, egyetemi (master) és doktori (PhD) képzések indultak. Az 1950-es évek végétől megalakultak Európában, Ázsiában is a regionális tudományi szervezetek, a nemzetközi szervezet első elnöke Walter Isard lett, aki két egymást követő ciklusban, 1957-58-ban és 1958-59-ben töltötte be ezt a posztot. A különböző kontinensek tudományos társaságait egyesítve 1990-ben jött létre a Nemzetközi Regionális Tudományi Társaság (RSAI, Regional Science Association International), a formálisan megszünő RSA jogutódjaként. A dinamikus terjeszkedésre jellemző, hogy az RSAI-nak jelenleg mintegy 4500 tagja van.

Isard 1979-ben egyetemet váltott, és átment a Cornell University-re (ahol már korábban, 1973-tól megszervezte a regionális tudományi PhD-képzést), de ekkortól munkásságában háttérbe szorult a regionális tudomány. Főleg a Béketudomány (peace science) vált érdeklődésének fő területévé, megalapította a Békekutató Társaságot (Peace Research Society), ami később Béke Tudományos Társasággá (Peace Science Society) változott, elsősorban a konfliktus menedzsment, lefegyverzés és a fenntartható fejlődés kutatására fókuszálva. A tudományág váltásához a motivációt az is jelenthette, hogy Isard fiatal korában áttért a kvéker vallásra, emiatt a II. világháborúban megtagadta a fegyveres szolgálatot, és egy kórházban végzett szociális tevékenységet (ekkor fordította németböl angolra az említett alapvető müveket).

Walter Isard mindegy 25 könyvet és 300 tudományos tanulmányt publikált, amelyek meghatározó jelentőségűek a regionális tudomány szempontjából. Főleg elméleti és módszertani szempontból végzett kutatásainak fókuszában a városok és régiók rendszerei álltak. Mint a regionális tudomány megalapítója, az érdemei elvitathatatlanok egy új tudományág megszületésében és sikeres megszerveződésében. 
Walter Isard legfontosabb müvei:

Isard, W. (1956) Location and Space-economy. A General Theory Relating to Industrial Location, Market Areas, Land Use, Trade, and Urban Structure. MIT Press, Cambridge (MA) and Wiley, New York.

Isard, W. (1959) Industrial Complex Analysis and Regional Development; a Case Study of Refinery-petrochemical-synthetic-fiber Complexes and Puerto Rico. MIT Press (MA), Cambridge.

Isard, W. (1960) Methods of Regional Analysis; an Introduction to Regional Science. MIT Press, Cambridge and Wiley, New York.

Isard, W. (1969) General Theory: Social, Political, Economic, and Regional, with Particular Reference to Decision-making Analysis. MIT Press, Cambridge (MA).

Isard, W. (1971) Regional Input-output Study: Recollections, Reflections, and Diverse Notes on the Philadelphia Experience. Cambridge, M.I.T. Press.

Isard, W. (1972) Ecologic-economic Analysis for Regional Development; Some Initial Explorations with Particular Reference to Recreational Resource Use and Environmental Planning. Free Press, New York.

Isard, W. (1975) Introduction to Regional Science. Prentice-Hall, Englewood Cliffs. Isard, W. (2003) History of Regional Science and the Regional Science Association International: The Beginnings and Early History. Springer, Berlin.

\section{Jegyzet}

${ }^{1}$ Nekrológomban felhasználom a Regional Science Association International honlapján megjelent (http://www.regionalscience.org/Search.html?ordering=\&searchphrase=all\&searchword=isard), a Cornell University által is átvett, David Boyce által összeállított méltatást, valamint 'A regionális tudomány „térnyerése”: reális esélyek, avagy csalfa délibábok?’ címủ (Tér és Társadalom, 2010. 3., 1141.o.) tanulmányom több részletét.

Összeállította: Lengyel Imre, az MTA Regionális Tudományos Bizottság elnöke, a Szegedi Tudományegyetem egyetemi tanára. 